\title{
Availability and safety of blood transfusion during humanitarian emergencies
}

Yetmgeta Abdella, ${ }^{1}$ Rana Hajjeh ${ }^{1}$ and Cees Th. Smit Sibinga ${ }^{3}$

'World Health Organization Regional Office for the Eastern Mediterranean, Cairo, Egypt (Correspondence to: Y.E. Abdella: abdellay@who.int). ${ }^{2}$ International Quality Management (IQM) Consulting, Zuidhorn, Netherlands.

\begin{abstract}
Background: Availability and safety of blood transfusion is a major concern in countries affected by humanitarian emergencies. These emergencies increase demand for blood transfusion and make its delivery challenging and complex. Nevertheless, there is a lack of information on emergency preparedness and response capacity of blood transfusion services and on the challenges in meeting patients' needs.
\end{abstract}

Aims: To assess availability and safety of blood transfusion during humanitarian emergencies.

Methods: We searched PubMed and Index Medicus for the World Health Organization Eastern Mediterranean Region for data on availability and safety of blood transfusion during humanitarian emergencies. We also gathered information through a survey and during a regional consultation in Tunisia.

Results: We found 24 publications on disaster from 5 countries in the Region and 16 publications on disaster preparedness and blood transfusion in casualties and severe trauma outside the Region. However, none dealt with availability and safety of blood transfusion during humanitarian emergencies. Armed conflicts and terrorism, flooding and earthquakes are the most frequent emergencies with $10-85 \%$ of the injured requiring blood transfusion. There are gaps in emergency preparedness and response, including human resources, transport and cold chain, supply of consumables and maintenance of equipment, power supply, and finances.

Conclusions: There is a need to integrate blood transfusion services in the overall national emergency preparedness and response, and provide assistance to affected countries to address identified gaps. Recommendations for individual countries need to be tailor made, along the lines of the regional strategic framework for blood safety and availability.

Keywords: blood transfusion, blood safety, armed conflicts, humanitarian emergency, preparedness

Citation: Abdella Y; Hajjeh R; Smit Sibinga C. Availability and safety of blood transfusion during humanitarian emergencies. East Mediterr Health J. 2018;24(8):778-788. https://doi.org/10.26719/2018.24.8.778

Received: 16/02/17; accepted: 17/10/17

Copyright (C) World Health Organization (WHO) 2018. Some rights reserved. This work is available under the CC BY-NC-SA 3.0 IGO license (https:// creativecommons.org/licenses/by-nc-sa/3.o/igo).

\section{Introduction}

An average of 700 emergencies were reported annually during the first decade of this century (1). More than 250 million people are affected by emergencies with 110000 deaths every year from emergencies, excluding deaths from conflict (2). During humanitarian emergencies caused by conflicts, health care is increasingly under attack with violence against patients, health facilities and workers (3). This is a major concern and the World Health Organization (WHO) regularly raises this issue with Member States and advocates appropriate measures to be taken to protect healthcare services. Damage to health and health systems causes setbacks to a range of global health targets. Right now an unprecedented 130 million people are in need of aid globally, including the highest number of internally displaced people and the second largest number of refugees ever recorded globally (4).

The Eastern Mediterranean Region has the largest number of high-level and protracted emergencies and carries the largest burden of displaced populations (refugees and internally displaced people) globally. It has almost 30 million (52\%) of the worldwide 58 million displaced people (5), which places a significant burden on the national health systems and blood transfusion service programmes. Approximately 76 million people in the Region live in countries with humanitarian emergencies and $>10$ million people are internally displaced (6). The Region includes some of the most challenging countries in the world with humanitarian emergencies. Public health is facing a lot of challenges, currently driven mainly by political developments. Comparison of health provision with the provision of other needs during emergencies, such as water and food, shows that delivering health is challenging because health is more complex and has several determinants, and humanitarian emergencies make health a more urgent priority.

WHO has been at the forefront of the movement to improve blood safety and availability as mandated by successive World Health Assembly Resolutions of 1975, 2005 and 2010 and Regional Committee for the Eastern Mediterranean Resolutions of 1987 and 2016 (7). A lot of progress has been made in the Region, although many countries still face major challenges in ensuring availability, safety, quality, accessibility, affordability and clinical efficacy of blood transfusion. Humanitarian 
emergencies and armed conflicts have increased the demand for blood transfusion and made its delivery challenging and complex, requiring disaster-specific blood delivery systems and management approaches, as well as close coordination and cooperation among all stakeholders (8). This is partly because health systems have been weakened as a result of armed conflict, displacement of populations, and other complex emergencies. Also, the degree of development of the health systems differs among countries, with some being more advanced than others when emergencies have arisen.

The WHO Regional Office for the Eastern Mediterranean is actively engaged in assisting people affected by humanitarian emergencies through risk mitigation and robust emergency preparedness, response and recovery efforts $(9-11)$. Despite a variety of operational challenges, the Regional Office looks forward to supporting the creation of a resilient national action plan for the provision of blood transfusion services in emergencies, and using a robust monitoring framework to improve these plans iteratively as part of the overall national emergency preparedness and response efforts.

The purpose of this study was to collect available literature from the Region on availability and safety of blood in humanitarian emergencies, and collect data from the Member States on the current status of availability and safety of blood in humanitarian emergencies to allow gap analysis, identification of challenges, and recommendations for improvements.

\section{Methods}

A literature review was conducted on availability and safety of blood transfusion in humanitarian emergencies using PubMed and Index Medicus for the WHO Eastern Mediterranean Region. The search included publications from countries in the Region and beyond. Information on the status of availability and safety of blood transfusion during humanitarian emergencies in the Region was also collected using a survey questionnaire that was developed in collaboration with International Quality Management Consulting, the Netherlands (12). This questionnaire was sent to the 22 countries in the Region and covered: (1) type of emergencies over the past 10 years; (2) current strategies to ensure availability and safety of blood transfusion during emergencies; (3) coordination and collaboration between countries; and (4) gaps and challenges (Table 1). In addition, a regional consultation on the availability and safety of blood transfusion during humanitarian emergencies was organized in May 2016 in Tunis, Tunisia by the WHO Regional Office for the Eastern Mediterranean in collaboration with WHO headquarters (13). The objective of the consultation was to provide an overview of the status of blood transfusion service preparedness and response during humanitarian emergencies and to develop recommendations to strengthen the capacity of national blood transfusion services to respond to increased demand during humanitarian emergencies. Data entry and analysis of the survey was done using Microsoft Office Excel (2010 version).

\section{Results}

\section{Literature review}

An extensive search was done using PubMed and the specialized search machine of Index Medicus for the WHO Eastern Mediterranean Region (14) for 2000-2016. The key reference word "humanitarian emergency" did not exist in both indexes, therefore the search focused on "disaster", "armed conflict" and "war" in combination with "blood availability", "blood safety", "blood supply", "blood procurement", "blood processing" and "blood transfusion". Publications on disaster were identified from Afghanistan $(n=2)$, Egypt $(n=2)$, Islamic Republic of Iran ( $(n=11)$, Pakistan $(n=8)$ and Tunisia $(n=1)$. Additionally, several international publications $(n=18)$ regarding disaster preparedness and blood transfusion in casualties and severe trauma due to war, armed conflict, bomb blasts and civilian mass casualty events were studied (15-24). However, none dealt with the questions of availability and safety of blood transfusion during humanitarian emergencies. There were some publications related to transport and accessibility of blood. The Iranian and Pakistani publications were almost exclusively related to natural disasters such as earthquakes (25-41), and bomb blasts and terrorist attacks $(42,43)$. Some of the publications provide information on administrative and organizational structures for the management of disasters $(25,30,31,40-45)$ and on health problems arising from internal population displacement (36). These describe the managerial structure for natural disasters, with a small paragraph on terrorist attacks and bomb blasts.

WHO has published policies and technical guidelines on emergency risk management and humanitarian response, including the 2016 WHO Humanitarian Response Plan (46) and the 2016 WHO Health Emergencies Programme (WHE) update documents on progress and priorities $(47,48)$. None of these documents pays attention to the problems of availability and safety of blood transfusion during humanitarian emergencies and specific approaches for the management of blood service delivery in emergencies. The 2016 Humanitarian Response Plan describes the situation in 25 countries, of which $9(36 \%)$ are in the Eastern Mediterranean Region. The WHE has classified emergencies into 4 grades for acute crises (Table 2). There were 3 countries in the Region with grade 3 emergencies, 1 with a grade 2 emergency, 3 with grade 1 emergencies and 6 with ungraded emergencies (Table 3). In 2016, WHO responded to 47 emergencies, among which, 31 were acute and 16 were protracted.

Among the international publications are 3 instructive manuscripts in the category "How do I ...?" that might be useful in the practical clinical support of blood and blood products during protracted humanitarian emergencies, provided blood and blood products are available (49-51).

\section{Survey on availability and safety of blood transfusion during humanitarian emergencies}

The WHO Eastern Mediterranean Region comprises 21 


\section{Table 1 World Health Organization Eastern Mediterranean Region survey on availability and safety of blood transfusion during} humanitarian emergencies 2006-2016

\section{Type of emergency}

Natural - earthquake $(n=2)$, flooding $(n=4)$, drought $(n=1)$, landslide $(n=1)$, avalanche $(n=1)$, fire $(n=1)$

Human-made - terrorism $(n=10)$, war (including war in neighbouring countries) $(n=9)$, insurgency $(n=2)$, blockade $(n=2)$

These emergencies affect $20-100 \%$ of the community with estimated $10-85 \%$ of the injured requiring blood transfusion

Need for blood transfusion has increased in all countries due to the humanitarian emergencies

Type of emergencies has also changed over t he years - increasing conflicts and wars, explosions, acts of terrorism, refugees and population movements

Emergencies affect both military personnel and civilians - women, men, children and old people.

Main reasons for transfusion were:

- Trauma (armed conflict) $(\mathrm{n}=11)$

- Trauma (civil accident) $(\mathrm{n}=9)$

- Trauma (natural disaster) $(\mathrm{n}=1)$

- Obstetric $(\mathrm{n}=6)$

- Surgical (regular) $(n=6)$

- Paediatric anaemia (e.g., malaria, thalassaemia and haemophilia) $(\mathrm{n}=4)$

- Other (oncology) $(\mathrm{n}=3)$

\section{Current strategies}

Seven countries have a national emergency plan and strategy

Potential blood donors are mobilized through:

- Public media ( $\mathrm{n}=11)$

- Calling known donors $(\mathrm{n}=5)$

- Calling family/replacement donors $(\mathrm{n}=3)$

- Supply from neighbouring blood centres $(\mathrm{n}=7)$

- Other $(\mathrm{n}=1)$ - inter country collaboration

Only in 7 countries does the plan include emergency stocks in the blood centres and hospitals

- Coordinated by ministries of health, provincial health departments, and NGOs

- All countries process blood and test for $\mathrm{ABO}$ antigens, Rhesus D antigen, $\mathrm{HBV}, \mathrm{HCV}, \mathrm{HIV}$ and syphilis before issuing except:

- One country where syphilis testing is not done

- Two countries issued blood with incomplete crossmatch

Operational cold chain in place for transportation of blood and blood products in 9 countries

Power supply during emergencies has variable reliability

\section{Coordination and collaboration}

Central coordinating organization is in place in 10 countries

Collaboration between different blood supply organizations and between the different medical and emergency providers is limited

In 8 countries, NGOs are involved in humanitarian emergency responses

Only in 5 countries are NGOs involved in blood supply and transfusion (including donor mobilization) - covering 20-30\% of the total supply

\section{Gaps and challenges}

Most common weak points in the blood supply during emergencies are:

- Fragmented organization $(n=9)$

- Shortcomings in numbers and competence of human resources $(n=9)$

- Shortages in supply of consumables $(n=8)$

- Shortcomings in infrastructure $(\mathrm{n}=7)$

- Transport and cold chain deficits $(n=7)$

- Financial shortage $(\mathrm{n}=7)$

- Ineffective coordination $(n=6)$

$\mathrm{HBV}=$ hepatitis $\mathrm{B}$ virus; $\mathrm{HCV}=$ hepatitis $C$ virus; $\mathrm{HIV}=$ human immunodeficiency virus; $\mathrm{NGO}=$ nongovernmental organization.

Member States and the occupied Palestinian territory (West Bank and Gaza Strip), with a population of nearly 583 million people, which in 2012, according to World Population Prospects, United Nations, New York, 2013 (52) was around 606 million. There are currently 12 countries suffering from humanitarian emergencies with disruption of infrastructure including health care, education, transportation and access to clean water and energy.

The literature review shows that information is lacking on the status, successes and challenges in ensuring the availability and safety of blood transfusion during humanitarian emergencies. Afghanistan, Egypt, Islamic Republic of Iran, Jordan, Lebanon, Libya, Pakistan, occupied Palestinian territory, Somalia, Sudan,
Syrian Arab Republic and Tunisia responded to the survey assessing the status of availability and safety of blood transfusion during humanitarian emergencies, including 10 countries (those listed, with the exception of Islamic Republic of Iran and Tunisia) currently affected by humanitarian emergencies. The survey response covers countries with a combined population of $>500$ million ( $84 \%$ of the population in the Region). Some of these countries have absorbed huge numbers of refugees, for example, Jordan with a population of 6.6 million Jordanians hosts 3 million refugees from Iraq, occupied Palestinian territory and the Syrian Arab Republic, and Lebanon with 4.5 million Lebanese hosts 1.5-2 million refugees from the Syrian Arab Republic (5,53), adding a 
considerable burden to the host health system.

\section{Type of emergencies over the past 10 years}

Among the natural emergencies reported there were earthquakes (Afghanistan, Islamic Republic of Iran and Pakistan), flooding (Afghanistan, Pakistan, Somalia and Sudan), drought (Afghanistan), landslide (Afghanistan), avalanche (Afghanistan) and fire (Somalia). The human-made emergencies included terrorism (Egypt, Jordan, Pakistan, Lebanon, Libya, occupied Palestinian territory, Syrian Arab Republic and Tunisia); war, including armed conflict in neighbouring countries (Islamic Republic of Iran, Jordan, Lebanon, Libya, occupied Palestinian territory, Sudan and Syrian Arab Republic); insurgency (Lebanon); and blockade (Lebanon and Syrian Arab Republic). These emergencies affect between 20 and 100\% of the communities with an estimated $10-85 \%$ of the injured requiring blood transfusion.

The main reasons for blood transfusion were increased numbers of injuries and trauma as a result of war and armed conflict (Afghanistan, Egypt, Jordan, Lebanon, Libya, Pakistan, occupied Palestinian territory, Somalia, Sudan, Syrian Arab Republic and Tunisia); civil accident trauma (Afghanistan, Egypt, Islamic Republic of Iran, Jordan, Lebanon, Libya, Pakistan, Sudan and Syrian Arab Republic); and trauma due to natural disaster (Islamic Republic of Iran and Pakistan). Due to limited availability of blood during these emergencies, the need for blood transfusion could not be met for emergency obstetric care (Afghanistan, Lebanon, Libya and Pakistan); elective surgery (Afghanistan, Lebanon, Libya, Pakistan, Somalia and Syrian Arab Republic); paediatric anaemia due to malaria, haemoglobinopathy (thalassaemia and sickle cell disease) and haemophilia A and B (Afghanistan, Lebanon, Pakistan and Syrian Arab Republic); and other reasons, for example, oncology (Egypt, Lebanon and Sudan).

\section{Current strategies to ensure availability and safety of blood transfusion during emergencies}

National emergency/contingency plans to respond to threatening and disastrous events were reported from Afghanistan (2015), Egypt (2014), Islamic Republic of Iran (2014), Jordan (2009), Lebanon (2006), Pakistan (2010), occupied Palestinian territory (1994), Syrian Arab Republic (2011) and Tunisia (2004). In Libya, Somalia and Sudan no emergency or contingency plan has yet been developed.

These plans vary between countries and include a disaster risk management system (Afghanistan), emergency preparedness plan (Afghanistan and Lebanon), disaster response management plan (Islamic Republic of Iran), emergency blood donation teams (Lebanon), and various responsible bodies such as High National Council of Crisis Management (Jordan), National Disaster Management Commission and Authority (Pakistan) and Red Cross/Crescent (Lebanon and occupied Palestinian territory). The main immediate actions focus on blood donor mobilization through public and social media, mosques, increased mobile blood collection team sessions, use of emergency or strategic blood stocks, and support from blood centres in neighbouring cities and provinces. Collaboration and coordination with and between various groups to mobilize blood donors is reported by Afghanistan, Islamic Republic of Iran, Jordan, Lebanon, Pakistan and occupied Palestinian territory. Potential blood donors are mobilized through public media (8 countries) or direct appeal to regular donors (3 countries) and family/replacement donors (3 countries). Seven of the responding countries to the survey do keep an emergency or strategic blood stock (Egypt, Jordan, Pakistan, occupied Palestinian territory, Sudan, Syrian Arab Republic and Tunisia), coordinated in 5 countries by the Ministry of Health or Ministry of Interior Affairs. In Pakistan the coordination is in the hands of the Provincial Health Departments and in Lebanon there is no regular emergency stock. However, in case of emergencies coordination is done by the Lebanese Red Cross Society.

All responding countries process and test blood during humanitarian emergencies, although Lebanon, Libya, Pakistan, the occupied Palestinian territory, Sudan and the Syrian Arab Republic still issue whole blood for trauma and surgical indications. Testing for $A B O$ and Rhesus D antigens, hepatitis B virus, hepatitis $C$ virus and human immunodeficiency virus is done in all countries even during emergencies. In Somalia, testing for transfusion-transmitted infection markers is done exclusively by rapid tests, whereas Afghanistan, Pakistan, the occupied Palestinian territory, Sudan and the Syrian Arab Republic use both rapid tests and enzyme-linked immunosorbent assays. Libya, Pakistan and the occupied Palestinian territory use chemiluminescence assays for viral markers. For transportation of blood and blood products over long distances, Afghanistan, Lebanon and Somalia do not have an operational cold chain in place.

Under emergency situations, particularly when protracted, power supply becomes a serious problem, due to system failure as well as fuel shortage. Poor to non-reliability of power supply was reported in Afghanistan and Pakistan. Egypt, the Islamic Republic of Iran, Jordan, the occupied Palestinian territory and the Syrian Arab Republic reported acceptable or satisfactory reliability. However, Lebanon reported a major problem during terrorist attacks and blockades. Libya reported a reasonably reliable power supply. Sudan reported variable reliability of the power supply and Somalia reported that some blood centres suffered from absence of a reliable power supply. Operational emergency power supply was reported in 8 countries (Egypt, Islamic Republic of Iran, Jordan, Lebanon, Libya, Pakistan, occupied Palestinian territory and Syrian Arab Republic). Afghanistan and Somalia reported the absence of a stand-alone emergency power supply in the blood bank or hospital. In Sudan and Tunisia, a stand-alone emergency power supply in the blood bank or hospital is not always available.

\section{Coordination and collaboration}

Central coordinating organization for blood transfusion service emergency response is in place in 10 of 12 countries, but is not well structured in Afghanistan and Libya. Central coordination is accomplished in Egypt by the $\mathrm{Na}$ - 


\begin{tabular}{|c|c|}
\hline Ungraded & An event that is being assessed, tracked or monitored by WHO but that requires no WHO response at the time. \\
\hline Grade 1 & $\begin{array}{l}\text { A single or multiple country event with minimal public health consequences that requires a minimal WCO response } \\
\text { or a minimal international WHO response. Organizational and/or external support required by the WCO is minimal. } \\
\text { The provision of support to the WCO is coordinated by a focal point in the regional office. }\end{array}$ \\
\hline Grade 2 & $\begin{array}{l}\text { A single or multiple country event with moderate public health consequences that requires a moderate WCO } \\
\text { response and/ or moderate international WHO response. Organizational and/or external support required by the } \\
\text { WCO is moderate. An Emergency Support Team, run out of the regional office, coordinates the provision of support to } \\
\text { the WCO. }\end{array}$ \\
\hline Grade 3 & $\begin{array}{l}\text { A single or multiple country event with substantial public health consequences that requires a substantial WCO } \\
\text { response and/ or substantial international WHO response. Organizational and/or external support required by the } \\
\text { WCO is substantial. An Emergency Support Team, run out of the regional office, coordinates the provision of support } \\
\text { to the WCO. }\end{array}$ \\
\hline
\end{tabular}

WCO = WHO country office.

tional Blood Transfusion Center in Cairo; in the Islamic Republic of Iran by the Iranian Blood Transfusion Organization in Tehran; in Jordan by the National High Commission for Crisis Management in Amman; in Lebanon by the joint Red Cross Blood Banks; in Pakistan by the Safe Blood Transfusion Program and the Federal Ministry of National Health Services, Coordination and Regulation in Islamabad; in the occupied Palestinian territory by the Ministry of Health; in Sudan by the National Blood Transfusion Centre in Khartoum; in the Syrian Arab Republic by the Establishment for Blood Transfusion and Medical Industries in Damascus; and in Tunisia by the Unite de Transfusion Sanguine et des Banques de Sang at the Ministry of Public Health in Tunis. Information from Somalia was not provided.

Collaboration between different blood supply organizations exists only in Jordan, Lebanon, Pakistan, Sudan and Tunisia; Afghanistan did not respond to this question. Collaboration between the different medical and emergency care providers does not exist in Afghanistan, Egypt, Libya, Somalia and Sudan. In the 7 countries where there is collaboration, responsibilities are with the Ministry of Health in the Islamic Republic of Iran, occupied Palestinian territory and Syrian Arab Republic. Responsibility for cooperation is with the National High Council of Crisis Management in Jordan, the Coordinator of the Senior Emergency Committee in Lebanon, and the Provincial Health Departments and their Blood Programs and with the Pakistan Red Crescent Society in Pakistan. In Afghanistan, Islamic Republic of Iran, Lebanon, Libya, Pakistan, occupied Palestinian territory, Sudan, Syrian Arab Republic and Tunisia, nongovernmental organizations (NGOs) are involved in blood transfusion services during humanitarian emergency responses. In most of these countries the NGO is the national Red Cross/Red Crescent Society, but in Sudan the Youth Organization is involved in donor motivation and mobilization, and in Afghanistan and Pakistan, apart from the Red Crescent Society, there are other NGOs with which collaboration has been established. Only in Afghanistan, Lebanon, Libya, Pakistan and Tunisia are NGOs involved in actual blood supply and transfusion (including donor mobilization) - covering at least 20-
$30 \%$ of the total supply. These NGOs were all reported to have formal permission, with the exception of in Libya.

\section{Gaps and challenges}

More than half of the countries indicated the following weaknesses in their blood supply during humanitarian emergency situations: political instability $(n=6)$, fragmented organization $(n=9)$, ineffective coordination (n $=6$ ), shortcoming in numbers and competence of human resources $(n=8)$, transport and cold chain deficits $(n=$ $8)$, shortages in supply of consumables $(n=7)$, maintenance of equipment $(n=6)$ and shortage in finances $(n=$ 7). Afghanistan, Libya, Somalia and Sudan reported serious challenges. There was commonality in the top challenges indicated by countries such as competent human resources, political commitment, finances and shortages of consumables.

\section{Regional consultation on blood availability and safety during humanitarian emergencies}

The regional consultation was held in Tunis, Tunisia, from 15 to 16 May 2016. The consultation was attended by directors of national blood transfusion services from 10 of the 12 countries involved in humanitarian emergencies. Iraq and Yemen were not represented. Also in attendance were experts from Indonesia, the Netherlands, Tunisia, United Kingdom of Great Britain and Northern Ireland, and Zimbabwe, and representatives of international and regional organizations including Africa Society of Blood Transfusion, Arab Transfusion Medicine Forum, Médecins Sans Frontières, as well as from WHO headquarters. The participants reviewed the status, successes, challenges and lessons learned in ensuring the availability and safety of blood transfusion during humanitarian emergencies through a semistructured group discussion, and adopted a set of recommendations to strengthen blood transfusion services to respond to the increased demand during humanitarian emergencies.

\section{Discussion}

Humankind has faced many hazards, some of which have developed into disaster situations where a humanitarian response has been necessary. The extent of the humani- 


\begin{tabular}{|c|c|c|c|}
\hline Grade 3 emergencies $(n=5)$ & $\begin{array}{l}\text { Grade } 2 \text { emergencies } \\
(n=12)\end{array}$ & $\begin{array}{l}\text { Grade } 1 \text { emergencies } \\
\qquad(n=14)\end{array}$ & $\begin{array}{l}\text { Ungraded protracted } \\
\text { emergencies }(n=16)\end{array}$ \\
\hline Iraq ${ }^{\underline{a}}$ & Angola & Afghanistan $^{\mathrm{a}}$ & Burkina Faso \\
\hline Nigeria & Cameroon & Bangladesh & Chad \\
\hline South Sudan & Central African Republic & Democratic People's Republic of Korea & Colombia \\
\hline Syrian Arab Republic ${ }^{a}$ & $\begin{array}{l}\text { Democratic Republic of the } \\
\text { Congo }\end{array}$ & Fiji & Djibouti $^{\text {a }}$ \\
\hline \multirow[t]{12}{*}{ Yemen $^{\text {a }}$} & Ecuador & Indonesia & Egypt $^{\mathrm{a}}$ \\
\hline & Ethiopia & Kenya & Gambia \\
\hline & Haiti & Mali & Guatemala \\
\hline & Libya $^{\text {a }}$ & Nepal & Honduras \\
\hline & Myanmar & Pakistan $^{a}$ & Jordan a \\
\hline & Niger & Papua New Guinea & Lebanon ${ }^{\text {a }}$ \\
\hline & Ukraine & Philippines & Mauritania \\
\hline & United Republic of Tanzania & Sri Lanka & Senegal \\
\hline & & Thailand & Somalia a \\
\hline & & West Bank and Gaza Strip ${ }^{a}$ & Sudan ${ }^{a}$ \\
\hline & & & Turkey \\
\hline & & & Zimbabwe \\
\hline
\end{tabular}

${ }^{a}$ WHO Eastern Mediterranean Region.

tarian situation has varied depending on the level of resilience of the various systems in which the hazards have occurred. Healthcare systems have developed over the years to respond better to these situations, with the aim of having a system that is robust enough to prevent the hazard from spiralling into a disaster situation. In order to achieve this, basic infrastructure, sustained and committed governance and leadership, integrated healthcare planning and technical and scientific understanding are needed.

WHO has responded to many humanitarian crises, assessing risks, analysing, prioritizing and responding to critical health situations with relevant resources and focused relief missions. Obviously, there are more organizations such as the International Federation of Red Cross and Red Crescent Societies, and Médecins sans Frontière that are involved in providing support during humanitarian emergencies and natural disasters. So far, the relief missions and reports related to humanitarian emergency situations have paid only limited attention to the need to document and publish the important aspects of supportive haemotherapy through availability and safety of blood transfusion during emergencies.

The 2016 Humanitarian Response Plans (54) listing the health priorities and WHO health sector projects in 25 countries (9 from the Eastern Mediterranean Region and 10 from the African Region) and 3 Regional Response plans (Sahel Regional Response Plan, South Sudan Regional Response Plan, and Syria Regional Refugee and Resilience Plan) do not explicitly mention the importance of availability and safety of blood transfusion during humanitarian emergencies, to meet the needs of wounded and injured individuals, women in labour and at risk of fatal obstetric bleeding, and thousands of children with haemoglobinopathy like thalassaemia and sickle cell disease or inherited coagulopathy such as haemophila A and B and von Willebrand disease or malaria anaemia.

Protracted humanitarian emergency situations and population displacement cause serious healthcare problems, not only because of the difficulties in reaching some areas, but also because of crumbling infrastructure, economic blockades hampering adequate supplies of essential medical consumables, including blood bags, test kits and spare parts, and limited availability of competent personnel and budgetary restrictions.

The survey conducted showed a clearer picture of the problems faced in maintaining availability and safety of the blood supply in the 12 affected countries. There were major deficiencies observed in their current strategies to respond to humanitarian emergencies, and coordination between and collaboration with different parties and organizations involved. Major gaps and challenges, including shortage of finance, reliable power supply, regular supplies and equipment maintenance were identified that may lead to a focused and stepwise approach in planning for action.

Critical aspects needed for securing availability and safety of blood and blood products in humanitarian emergencies include maintaining hygiene, disinfection, asepsis and infection prevention, cold chains, waste disposal, absence of a regular donor panel and management, high prevalence of hepatitis $B$ and $C$ viruses, supply lines, and maintenance and repair. Problems faced also include the logistics of supply, particularly into areas with limited or no access. In the Syrian Arab Republic 
blood and blood products are parachuted into besieged cities, but it is not known whether and in what conditions the supplies reach their intended destination. Currently, experiments are ongoing using drones for transportation over long distances into otherwise inaccessible places $(53,54)$. The first results reported are promising, although the experiments were done under normal peaceful circumstances. Availability of blood products, in particular red cells, can be achieved without the need for electricity or centrifuges. The use of gravity has long been practised, but never well standardized and studied. Gravity sedimentation has been used in Burkina Faso since 2008 and a recent academic study has provided evidence of the quality of the red cells produced using a closed triple bag system containing $100 \mathrm{ml} \mathrm{SAGM} \mathrm{(saline,} \mathrm{adenine,} \mathrm{glucose}$ and mannitol) solution (55). A more recent development allows standardized separation by gravity within a closed blood bag system with an integrated leukocyte depletion filter that is easy to handle (56). A major problem is the limitation in funding and shortages due to interruption of supplies of consumables. However, increasingly when power supply allows, there is use of social media to communicate with potential blood donors as well as with personnel in difficult-to-access areas.

The other major gaps and challenges experienced are the still fragmented and hospital-based organization of the blood supply; shortcomings in numbers and competence of available human resources; shortages in supplies of consumables; shortcomings in infrastructure, including power supply; dependence on fuel, transport and cold chain deficits and risks; financial shortages; and ineffective coordination. Seasonal climate changes may cause problems in logistics of supply and reaching potential donors with mobile teams for collection.

\section{Conclusions and recommendations}

The data presented reveal shortcomings and gaps in most of the countries in ensuring the availability and safety of blood transfusion during humanitarian emergencies. These shortcomings and gaps are of different weight and importance for each of the contributing countries. WHO Regional Office for the Eastern Mediterranean developed a Regional Strategic Framework for Blood Safety and Availability 2016-2025 (57) that recognizes the needs of the population suffering in humanitarian emergencies. The Strategic Framework was discussed in depth and agreed in consensus by all representatives of the Member States and was endorsed unanimously by the Regional
Committee for the Eastern Mediterranean (7). In addition to implementing the priority interventions described in the Regional Strategic Framework, the following recommendations were agreed during the Regional Consultation to achieve sustained availability and safety of blood during humanitarian emergencies.

1. Identify and work closely with authorities responsible for national emergency preparedness and response in order to highlight the importance of including blood transfusion services in overall national emergency preparedness and response activities.

2. Collect updated information on factors affecting provision of blood transfusion during humanitarian emergencies, and strategies, measures, procedures and priority actions to meet the increased demand for blood and blood products and blood transfusion during humanitarian emergencies.

3. Identify technical and financial assistance needs to improve capacity of blood transfusion services for emergency preparedness and response.

4. Strengthen coordination and collaboration among relevant stakeholders internally and between countries to integrate blood safety and availability measures in the overall health response mechanisms and other relevant sectors.

5. Review existing guidelines and tools to see what information may be leveraged for future guidance on this topic, and develop a short guidance document on managing blood transfusion services in humanitarian settings, including global minimum standards.

6. Establish an emergency blood service system and management expertise.

These recommendations need to be formulated for each country individually on a tailor-made basis along the lines of the Strategic Framework (58), and guided and advised on the short, medium and long term by WHO regional and country offices, and experienced and committed experts in the field of international development of transfusion medicine, with an emphasis on quality management. Countries should be advised to collaborate and cooperate actively, exchanging experiences and solutions to problems and challenges, coordinated through the Regional Office on a regular biannual accounting scheme.

\section{Acknowledgements}

The authors wish to express their thanks to the countries that participated in the survey; participants of the regional consultation on availability and safety of blood transfusion during humanitarian emergencies for their contributions; staff of the Regional Office for the Eastern Mediterranean Library for facilitating the literature review; Junping Yu, Adelheid Marschang, Hyo Jeong Kim and Valentina Hafner from WHO headquarters for reviewing the manuscript; and Humayun Asghar for providing guidance at the initial phase of development of the paper.

Funding: None.

Competing interests: None declared. 


\section{Approvisionnement en sang et sécurité transfusionnelle dans les situations d'urgence humanitaire}

\section{Résumé}

Contexte: L'approvisionnement en sang et la sécurité transfusionnelle sont des préoccupations majeures dans les pays affectés par les situations d'urgence humanitaire. Ces situations d'urgence sont à l'origine d'une augmentation de la demande en transfusions sanguines et rendent la réalisation de cette procédure difficile et complexe. Néanmoins, il existe un manque d'informations sur les capacités de préparation et de riposte des services de transfusion sanguine aux situations d'urgence, ainsi que sur les difficultés à répondre aux besoins des patients.

Objectifs : Évaluer l'approvisionnement en sang et la sécurité transfusionnelle dans les situations d'urgence humanitaire.

Méthodes : Nous avons effectué des recherches dans PubMed et l'Index Medicus pour la Région OMS de la Méditerranée orientale afin de trouver des données sur l'approvisionnement en sang et la sécurité transfusionnelle dans les situations d'urgence humanitaire. Nous avons également recueilli des informations au moyen d'une enquête et au cours d'une consultation régionale en Tunisie.

Résultats : Nous avons trouvé 24 publications sur les catastrophes naturelles dans cinq pays de la Région, et 16 publications sur la préparation aux catastrophes naturelles et la transfusion sanguine pour les blessés et les cas traumatologiques graves en dehors de la Région. Cependant, aucune ne traitait de l'approvisionnement en sang et de la sécurité transfusionnelle dans les situations d'urgence humanitaire. Les conflits armés et le terrorisme, les inondations et les séismes sont les situations d'urgence les plus fréquentes, avec 10 à $85 \%$ de blessés nécessitant des transfusions sanguines. Des lacunes existent en matière de préparation et de riposte aux situations d'urgence, notamment en ce qui concerne les ressources humaines, le transport et la chaîne du froid, l'approvisionnement en consommables et l'entretien des équipements, l'approvisionnement en électricité et les finances.

Conclusions : Il est nécessaire d'intégrer les services de transfusion sanguine au processus global de préparation et de riposte aux situations d'urgence au niveau national, ainsi que d'apporter une assistance aux pays affectés pour leur permettre de combler les lacunes identifiées. Les recommandations pour chaque pays doivent être faites sur mesure, conformément au cadre stratégique régional pour la sécurité transfusionnelle et la disponibilité des produits sanguins.

$$
\begin{aligned}
& \text { مدى تو افر وسلامة نقل الدم أثناء الطوارئ الإنسانية } \\
& \text { إيتمجيتا عبدالله، رنا حاجة، سيس سيبينجا }
\end{aligned}
$$

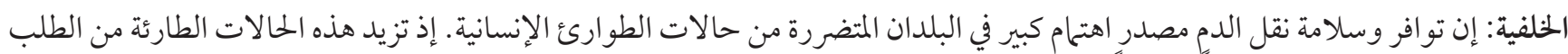

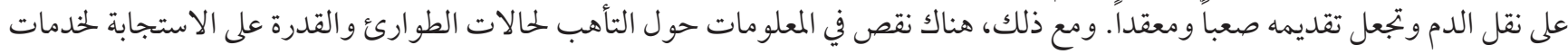

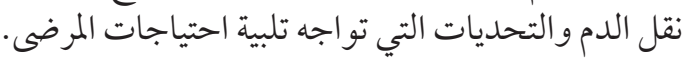
الأهداف: تقييم مدى تو افر وسلامة نقل الدم أثناء الطو ارئ الإنسانية.

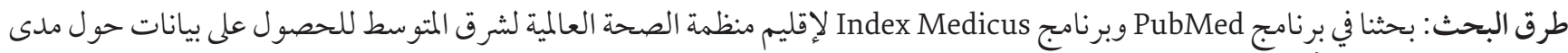

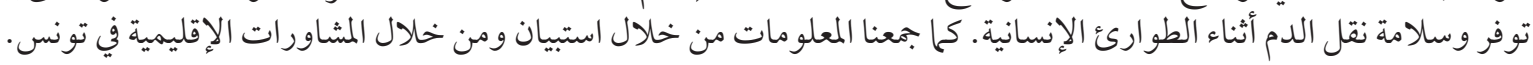

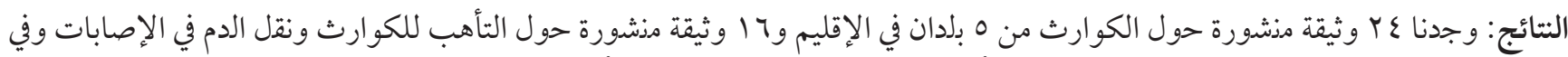

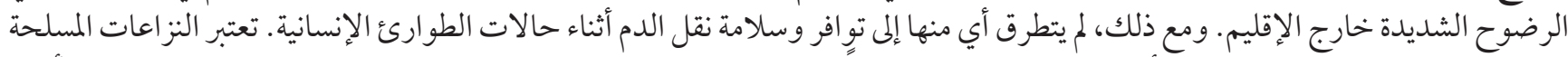

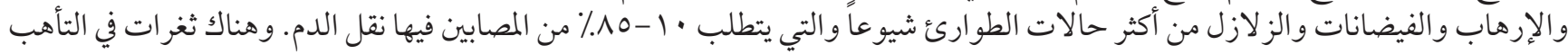

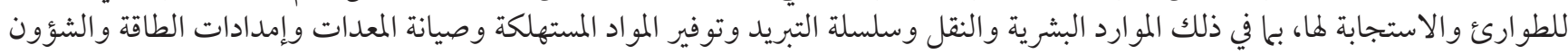

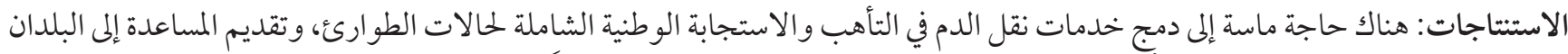

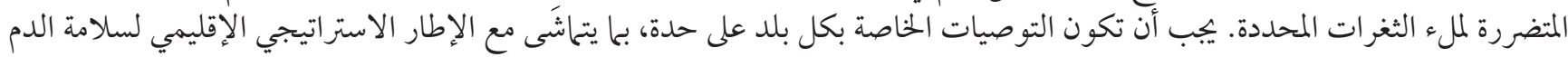
وتو افره. 


\section{References}

1. Emergency risk management and humanitarian response. Report 2013-2014. Geneva: World Health Organization; 2015 (http:// www.who.int/hac/erm_report2013_2014.pdf, accessed 27 March 2018)

2. World disasters report. Focus on hunger and malnutrition. Geneva: International Federation of the Red Cross and Red Crescent Societies; 2011 (http://www.ifrc.org/PageFiles/99868/Photos/wdr.pdf, accessed 27 March 2018)

3. WHO health emergencies. Attacks on health care [website]. Cairo: World Health Organization Regional Office for the Eastern Mediterranean (http://www.emro.who.int/eha/attacks-on-health-care/index.html, accessed 27 March 2018)

4. WHO's new health emergencies programme. World Health Organization; 2016 (http://www.who.int/about/who_reform/emergency-capacities/WHO-one-emergency-programme-24October2016.pdf?ua=1, accessed 27 March 2018)

5. WHO health emergencies. Displaced populations [website]. Cairo: World Health Organization Regional Office for the Eastern Mediterranean http://www.emro.who.int/eha/displaced-populations/index.html, accessed 27 March 2018)

6. Refugees and internally displaced persons in the Eastern Mediterranean Region: a health perspective. Cairo: World Health Organization Regional Office for the Eastern Mediterranean; 2015 (http://www.emro.who.int/images/stories/eha/documents/ migrants_refugees_position_paper.pdf?ua=1, accessed 27 March 2018)

7. Resolution. Regional Committee for the Eastern Mediterranean. Strategic framework for blood safety and availability $2016-2025$. EM/RC63/R.5 October 2016 (http://applications.emro.who.int/docs/RC63_Resolutions_2016_R5_19126_EN.pdf?ua=1, accessed 27 March 2018)

8. Universal access to safe blood transfusion. Geneva: World Health Organization; 2008 (WHO/EHT/08.03; http://www.who.int/ bloodsafety/publications/UniversalAccesstoSafeBT.pdf?ua=1, accessed 27 March 2018)

9. Shaikh IA, Musani A. Emergency preparedness and humanitarian action: the research deficit. Eastern Mediterranean Region perspective. East Mediterr Health J. 2006;12 Suppl 2:S54-63. PMID:17361678

10. Van Wassenhove LN. Humanitarian aid logistics: supply chain management in high gear. J Oper Res Soc. 2006;57(5):475-89. https://doi.org/10.1057/palgrave.jors.2602125

11. Loruntoba R, Gray R. Humanitarian aid: an agile supply chain? Supply Chain Manage Int J. 2006;11(2):115-20. https://doi. org/10.1108/13598540610652492

12. International Quality Management Consulting [website] (http://www.iqmconsulting.nl/, accessed 27 March 2018)

13. Summary report on the regional consultation on the availability and safety of blood transfusion during humanitarian emergencies. Tunis, Tunisia 15-16 May 2016 (WHO-EM/LAB/387/E; http://applications.emro.who.int/docs/IC_Meet_Rep_2016_EN_18967. pdf?ua=1, accessed 27 March 2018)

14. Library and Information Networks for Knowledge. Index Medicus for the Eastern Mediterranean Region [website]. World Health Organization (http://www.who.int/library/databases/emro/en/, accessed 27 March 2018)

15. Information resources. Index Medicus for the Eastern Mediterranean Region (IMEMR) [website]. World Health Organization Regional Office for the Eastern Mediterranean (http://www.emro.who.int/information-resources/imemr/imemr.html, accessed 27 March 2018)

16. Hess JR, Thomas MJG. Blood use in war and disaster: lessons from the past century. Transfusion. 2003 Nov;43(11):1622-33. https://doi.org/10.1046/j.1537-2995.2003.00576.x PMID:14617324

17. Schmidt PJ. Blood and disaster - supply and demand. N Engl J Med. 2002 Feb 21;346(8):617-20. https://doi.org/10.1056/ NEJM200202213460813 PMID:11856803

18. Spinella PC, Dunne J, Beilman GJ, O'Connell RJ, Borgman MA, Cap AP, et al. Constant challenges and evolution of US military transfusion medicine and blood operations in combat. Transfusion. 2012 May;52(5):1146-53. https://doi.org/10.1111/j.15372995.2012.03594.x PMID:22575063

19. Gonzales R, Taylor AL, Atkinson AJ, Malloy WW, Macdonald VW, Cap AP. US Army blood program: 2025 and beyond. Transfusion. 2016 Mar;56 Suppl 1:S85-93. https://doi.org/10.1111/trf.13338 PMID:27001366

20. Resar LMS, Wick EC, Almasri TN, Dackiw EA, Ness PM, Frank SM. Bloodless medicine: current strategies and emerging treatment paradigms. Transfusion. 2016 Oct;56(10):2637-47. https://doi.org/10.1111/trf.13736 PMID:27473810

21. Quillen K, Luckey CJ. Blood and bombs: blood use after the Boston Marathon bombing of April 15, 2013. Transfusion. 2014 Apr;54(4):1202-3. https://doi.org/10.1111/trf.12642 PMID:24724792

22. Sandler SG, Ouellette GJ. Transportation and other blood system issues related to disasters: Washington, DC experience of September 11, 2002. Vox Sang. 2002 Aug;83 Suppl 1:367-70. https://doi.org/10.1111/j.1423-0410.2002.tbo5336.x PMID:12617171

23. Glasgow S, Davenport R, Perkins Z, Tai N, Brohi K. A comprehensive review of blood product use in civilian mass casualty events. J Trauma Acute Care Surg. 2013 Sep;75(3):468-74. https://doi.org/10.1097/TA.obo13e318298efb9 PMID:23928738

24. Doughty H, Glasgow S, Kristoffersen E. Mass casualty events: blood transfusion emergency preparedness across the continuum of care. Transfusion. 2016 04;56 Suppl 2:S208-16. https://doi.org/10.1111/trf.13488 PMID:27100758

25. Rastegari H, Ajami A. An overview of the management of the crisis. J Inform Manag Health. 2005;2:73-8.

26. Haqqi S. Mental health consequences of disasters. Med Today (Karachi). 2006;4:102-6. 
27. Ahmed J, Mehraj V. Are we prepared to meet the growing challenges of disasters? J Ayub Med Coll Abbottabad. 2007 OctDec;19(4):140-1. PMID:18693620

28. Khankeh HR, Mohammadi R, Ahmadi F. Health care services at time of natural disasters: a qualitative study. Iran J Nursing. 2007;20:85-96.

29. Rezaeian M. Epidemiological approaches to disasters and emergencies within the Middle East Region. Middle East J Emerg Med. 2007;7:54-6.

30. Razapour R. Role of GIS in disaster management. Homa-ye-Salamat (A Journal on Policy, Quality and Management in Health System). 2008; 4(22):18-22.

31. Ojaghi S, Nourizad S, Mahboobi M, Khazaei AAR, Najafi GHA. Disaster crisis handling preparedness level of hospitals in Kermanshah. J Kermanshah Univ Med Sci. 2009 Fall;13(3):267-74

32. Klanmehr N, Mofidi M, Nejati A. Assessment of physician's knowledge about disaster. J Med Counc Islamic Rep Iran. 2009;27:264-73.

33. Jahangiri K, Tabibi SJ, Maleki M, Alamdari S. A comparative study on community-based disaster management (CBDM) in selected countries and proposing a model for Iran. J Iranian Inst Health Sci Res. 2009;8:49-57.

34. Nasiri Pour A, Reisi P, Nouri S. [Providing a standard operating process for health \& care rapid response team in Iran]. Q Sci J Relief Rescue. 2010;2:11-26 (in Persian).

35. Izadkhah Y. [Women and natural hazards: vulnerable in disasters or capable of disaster management]. Q Sci J Relief Rescue. 2010;2:71-80 (in Persian).

36. Shameen Ejaz S, Ara A. Trauma scale for disaster situations. Pak J Psychol. 2010;41:3-21.

37. Bile KM, Shadoul AF, Raaijmakers H, Altaf S, Shabib K. Learning through crisis: development and implementation of a health cluster strategy for internally displaced persons. East Mediterr Health J. 2010;16 Suppl:S82-90. PMID:21495593

38. Nekooei Moghadam M, Saeed S, Khanjani N, Arab M. What do we need to do for better casualty support in disasters. Iranian Red Crescent Med J 2011;13:512-13

39. Rashidi M, Rameshat M, Safe A, Gharib H. Disaster management in order to offset losses caused by the earthquake. Q Sci J Rescue Relief. 2011;3:40-7.

40. Zaheer HA. Blood management in disaster situations in Pakistan. ISBT Sci Ser. 2012;7(1):1-5. https://doi.org/10.1111/j.17512824.2012.01550.x

41. Zaheer HA, Waheed U. Blood transfusion service in disasters. Transfus Apheresis Sci. 2016 Oct;55(2):186-90. https://doi. org/10.1016/j.transci.2016.09.007 PMID:27665156

42. Zafar A, Cheema K, Yousaf A, et al. Major disasters - first-hand experience at DHQ Hospital in Rawalpindi. Rawal Med J. 1991;19:9-12.

43. Choudry ZA, Mahmood I, Khan AFA, Choudhry AM. Management of a mass disaster: An experience at Mayo Hospital in Lahore. Pak J Surg. 1996;12:156-9.

44. Abd El-Aziz M, Elbeih AA. Disaster preparedness during Hajj Season: Effect of training program on nurses knowledge and performance. New Egypt J Med. 1998;19:21-30.

45. Hussein E, Teruya J. Evaluation of blood supply operation and infectious disease markers in blood donors during the Egyptian revolution. Transfusion. 2012 Nov;52(11):2321-8. https://doi.org/10.1111/j.1537-2995.2012.03592.x PMID:23163293

46. Department for Emergency Risk Management and Humanitarian Response. 2016 WHO humanitarian response plans. Summary of health priorities and WHO projects in interagency humanitarian response plans. Geneva: World Health Organization; 2016 (http://www.who.int/hac/donorinfo/who_humanitarian_response_plan_2016_may.pdf?ua=1, accessed 27 March 2018)

47. Update. WHO Health Emergencies Programme: progress and priorities. Geneva: World Health Organization; 2016 (http://www. who.int/about/finances-accountability/funding/financing-dialogue/whe-update.pdf, accessed 27 March 2018)

48. Progress Report on the development of the WHO Health Emergencies Programme. 30 March 2016 (http://www.who.int/about/ who_reform/emergency-capacities/who-health-emergencies-programme-progress-report-march-2016.pdf?ua=1, accessed 27 March 2018).

49. Yuan S, Ziman A, Anthony MA, Tsukahara E, Hopkins C, Lu Q, et al. How do we provide blood products to trauma patients? Transfusion. 2009 Jun;49(6):1045-9. https://doi.org/10.1111/j.1537-2995.2009.02150.x PMID:19389035

50. Berg M, Justison G. How would I establish a perioperative blood salvage program? Transfusion. 2013 Sep;53(9):1888-93. https:// doi.org/10.1111/j.1537-2995.2012.03780.x PMID:22804916

51. Stubbs JR, Zielinski MD, Berns KS, Badjie KS, Tauscher CD, Hammel SA, et al. How we provide thawed plasma for trauma patients. Transfusion. 2015 Aug;55(8):1830-7. https://doi.org/10.1111/trf.13156 PMID:26013588

52. World population prospects. The 2012 revision. Highlights and advance tables. New York: United Nations, 2013 (ttp://esa.un.org/ unpd/wpp/publications/Files/WPP2012_HIGHLIGHTS.pdf, accessed 27 March 2018)

53. Amukele T, Ness PM, Toblan AAR, Boyd J, Street J. Drone transportation of blood products. Transfusion. 2017 Mar;57(3):582-8

54. Anonymous. Drones begin delivering blood in Rwanda. Blood is Life. AfSBT News Lett. 2016;2:2-3. 
55. Sawadogo S, Nébié K, Kafand E, et al. Preparation of red cell concentrates in low-income countries: efficacy of whole blood settling method by simple gravity in Burkina Faso. Int J Blood Transfus Immunohematol. 2016;6:20-9.

56. Bonn F, Büttner B, Krieter DH, Lemke H, Sauvant C. Blood separation and storage with a new gravity-driven device: performance with and without leukodepletion filter. Transfusion. 2016;56 Suppl S4:54A.

57. Strategic framework for blood safety and availability 2016-2025. Cairo: World Health Organization Regional Office for the Eastern Mediterranean; 2017 (WHO-EM/LAB/389/E; http://applications.emro.who.int/dsaf/EMROPub_2017_EN_19608.pdf?ua=1, accessed 27 March 2018).

58. Refugees and internally displaced persons in the Eastern Mediterranean Region. A health perspective. Cairo: World Health Organization Regional Office for the Eastern Mediterranean; 2015 (http://www.emro.who.int/images/stories/eha/documents/ migrants_refugees_position_paper.pdf, accessed 27 March 2018). 